Afrika Focus, Vol.7,Nr.3,1991,pp 193-221

\title{
REGIONAAL PARTICULARISME EN STAATSVOR- MING IN AFRIKA: DE DIOLA VAN ZUID SENEGAL IN HUN RELATIE MET DAKAR.
}

\section{John EICHELSHEIM}

Hoogte Kadijk $124 a$

1018 BT Amsterdam

Nederland

ONDERZOEKSVELD: stedelijke studies in ontwikkelingslanden (1)

\section{SUMMARY}

\section{REGIONAL PARTICULARISM AND STATE FORMATIONIN AFRICA: THE DIOLA IN SOUTHERN SENEGAL AND THEIR RELATIONSHIP WITH DAKAR}

In the French daily newspaper "Libération" of 8/9 september 1990 I read : "Reveil de la guerilla en Casamance. Two clashes occurred between the Senegalese army and MFDC guerillas on the 22th of august and the 4th of september; 16 soldiers and 24 guerillas were killed". A morbid déjd vu.

At the end of 1983, as I did my practical training in the town of Ziguinchor, in the south of Senegal, I witnessed some fierce clashes between the same participants, causing the death of some 200 people. How could this be happening in one of the most democratic states of Africa? Didn't the political arena of some 16 different parties give enough room for oppositional currents? The answer must be negative, in some cases. In this paper I want to show the reader that the articulation of local organizational structures and development policies of a modern state can cause many problems. In this case the typical dynamics of the Diola society in southern Senegal and the specific way of state formation in Senegal after Independence form an explosive mixture. 
In the first part of the paper a description is given of the dynamics of the Diola society by portraying the organizational structures in Diola villages before the colonial period. Then, in the colonial period, due to new influences as a result of the contacts with foreigners, some local organizational structures are politicized. Among the Diola this process of politicizing took place on a very low level because the Diola society has all the characteristics of a segmentary society. Each village formed an autonomous unit headed by elders. The use of power lays in the hands of a group rather than in the hands of an individual. For this reason the Diola never fully participated in the political arena, not even after Independence.

After Independence in 1960 the regimes in Dakar tried to impose their authority in all parts of the new state. First Leopold Senghor and then Abdou Diouf strived to form an omnipotent political party. A party in which all regional, ethnic and professional currants would be represented. This became the Parti Socialiste (PS). In the traditionally hierarchically organized societies in the North and the East of the state this was done by encapsulating powerful individuals. Once they joined the party they would bring along many followers or dependants as new members. But in the segmentary Diola society those political leaders did not exist. Therefore some individuals were dropped in the region by the PS to represent the inhabitants. These strangers were given a lot of power in the region. But it should be clear that these "representatives" were not accepted by local people who had the feeling of being colonized for the second time. This time by fellow countrymen from the North.

For the Dakar regimes, a way to impose their hegemony was connected to the say over land ownership. Since the adaption of the National Lands Act on the 17th of june 1964, all transactions concerning the control over land must be regulated via the local governments. One of the main consequences of this reform is that the state becomes the sole landlord of all the land. This implies that local, mostly ancient, land tenure systems have formally ceased to exist. With the case of the explosive growth of the city of Ziguinchor I show the impact of this reform on the surrounding Diola society. As control over local land is the crux of the organizational structures of Diola society, this new intrusion of the state caused an emotional reaction. Moreover because it was mostly done at random by politicians who had only eyes for their own goals. This being the result of the specific way the state strived for hegemony and attempted to graft new forms of organization on the segmentary Diola society. With explosively results!

KEY WORDS: Diola, politics, Senegal, social organisation, state formation, urban development 


\section{Inleiding}

"Torture: the Casamance Case", luidt de kop van het rapport van Amnesty International dat in mei 1990 is verschenen. Sinds 1983 kom ik bijna elk jaar in de Casamance regio, de strook land in het uiterste zuiden van Senegal, ingeklemd tussen Gambia in het noorden en Guinee Bissau in het zuiden (2). Behalve enige korte stukjes in de grote Franse dagbladen is dit de eerste keer dat de bloedige confrontaties tussen leger en aanhangers voor een grotere autonomie van de streek bredere aandacht krijgen. Dit, terwijl er sinds 1982 honderden doden en gewonden zijn gevallen en honderden arrestaties zijn verricht.

Eind 1983, tijdens mijn eerste verblijf in Ziguinchor, de grootste stad in de regio, heb ik onderzoek gedaan naar problemen rond de herverkaveling in de verschillende woonwijken. Een belangrijke informant, ene Mouhammed Kounta, is toen op 18 december ontvoerd en enige dagen later is zijn gruwelijk verminkte lijk gevonden (zie ook Livre Blanc, 1991). Voor mij een schokkende ervaring en hij blijkt het eerste burgerslachtoffer in de lange rij die nog zal vallen in de strijd tussen de regionale protestbeweging en het centrale bestuur in Dakar. Door literatuur studies en onderzoek ter plaatse ben ik meer te weten gekomen over de achtergronden van dit lokale protest.

De meest gangbare verklaringen voor het ontstaan en vooral het voortbestaan van deze protestbeweging - die zich de "Mouvement des Forces Démocratiques de Casamance" (MFDC) noemt - vinden hun oorsprong in geografische, ecologische en economische faktoren: zo zou de marginale ligging ten opzichte van de metropool Dakar en de daaraan gekoppelde geringe investeringsbereidheid van de overheid de voornaamste oorzaak zijn van een "onderontwikkelde" economische en culturele positie van Casamance ten opzichte van de rest van Senegal. Andere verklaringen voor deze onderontwikkeling worden gezocht in de geringe regenval van de laatste jaren.

Het gevoel als tweederangsburger te worden behandeld heeft de bewoners van Casamance een flinke dosis aversie tegen hun landgenoten in het noorden opgeleverd. En niet geheel ten onrechte. De verklaring van het regeringshoofd in het gezagsgetrouwe dagblad "Le Soleil" dat het enkel "een kleine groep koppige en domme boeren" betreft die zich in het bos verschuilt en wordt opgehitst en gesteund door buitenlandse mogendheden (de namen van Irak, Guinee Bissau en Mauretanië worden in dit verband nogal eens genoemd) vormt al een duidelijke aanwijzing hoe de regering van Abdou Diouf tegenover deze volksbeweging staat. 
Want dat het niet enkel een paar "domme boertjes" zijn die in opstand zijn gekomen en dat eigenlijk de hele ontstaansgeschiedenis van de jonge republiek Senegal debet is aan deze protestbeweging zal uit dit artikel moeten blijken.

Allereerst moeten wij ons afvragen hoe het mogelijk is dat in én van de meest democratische landen van het Afrikaanse continent, zoals Senegal toch algemeen bekend staat, lokaal verzet kan leiden tot zo een bloedige gebeurtenis. Geeft de democratische politieke arena, met al zijn pers- en politieke vrijheden geen ruimte voor de kanalisering van deze gevoelens van ontevredenheid? De focus van dit artikel zal een chronologische beschouwing zijn van de achtergronden die het ontstaan van deze protestbeweging onder de Diola en de huidige kracht ervan kunnen verklaren.

Deze historische benadering vangt aan met de beschrijving van lokale organisatievormen bij de Diola in de pré-koloniale periode. Hieruit komt een zeer gefragmenteerd leiderschap naar voren, in eerste instantie gebaseerd op "verwantschappelijke" afhankelijkheidsrelaties binnen een dorp waarin zeggenschap over grond een cruciale rol speelt. Schaalvergroting tijdens de koloniale en post-koloniale periode brengt de voordien tamelijk autonome dorpen in contact met bredere politiekeconomische ontwikkelingen. Tijdens deze elkaar opvolgende perioden proberen de verschillende regimes in Dakar het achterland hun macht op te leggen: de republiek Senegal ontstaat in 1960. Oude organisatievormen binnen de dorpssamenleving transformeren constant en markteconomie doet haar intrede. De "verwantschappelijke" dynamiek zorgt er echter voor dat er minder sprake is van louter op economische en politieke afweging gebaseerde afhankelijkheidsrelaties. Verwantschapsssolidariteit speelt nog steeds een belangrijke rol binnen de Diolasamenleving. Immers, het bloedige verloop van de protestuitingen in Casamance kan zeker niet alleen verklaard worden vanuit het perspectief van de staat die met alle geweld de boerensamenlevingen wil 'openbreken' voor de kapitalistische markteconomie.

Hiermee wordt ook direct duidelijk dat ik het proces van staatsvorming in Afrika wil interpreteren vanuit de optiek van een koppeling van oude, lokale machtsverhoudingen met nieuwe, moderne invloeden van buiten. Deze visie is voornamelijk gebaseerd op werk van de Franse antropologen en afrikanisten P.P.Rey en C.Meillassoux. Terwijl Meillassoux in 1975 de koppeling van dorpseconomieën aan de kapitalistische markteconomie als centraal thema hanteert waarbij hij constateert dat de ineenstorting van de domestieke zelfvoorzieningseconomie hiervan het enige resultaat kan zijn, richt Rey zich meer op de stuwende invloed van 'klassenallianties' - tussen kapitalistische belangengroeperingen en heersende klassen uit de produktiewijzen - op de vestiging van een kapitalistische dominantie. Beiden leggen grote nadruk op de cruciale rol die de staat speelt bij de koppeling van de 
verschillende produktiewijzen en het daaraan verbonden ontwikkelingsproces dat moet culmineren in de uiteindelijke dominantie van het kapitalisme over oudere produktiewijzen. Hiermee is ook direct het zwakke punt genoemd in de visie van beide afrikanisten omdat het vooralsnog niet duidelijk is welke invloed de verschillende actoren op dit proces kunnen uitoefenen.

Bewust geïnitieerde strategieën, door alle betrokken actoren en op elk levensterrein, dienen ook in beschouwing genomen te worden in analyses van staatsontwikkeling. Mijn interesse voor zo'n 'menselijke' invalshoek is aangewakkerd door de interpretaties van een andere groep Franse politicologen. Deze analyseren, onder invloed van Gramscis ideeën, het proces van staatsvorming in Afrika in termen van het streven van staatsregimes naar 'hegemonie' en van verborgen populaire reacties daartegenover. Volgens o.a. Bayart $(1979,1981,1983)$, proberen de regimes door initiatieven op alle mogelijke levensgebieden - door een 'action totalisante' - de bevolking in te kapselen in de nieuwe heerschappijverhoudingen, maar worden juist daardoor kwetsbaar voor allerlei 'modes populaires d'action politique' in de marge van het formele politieke domein (Geschiere, 1987: 41). De benadering van Bayart legt een direct verband tussen lokaal geïnitieerde protesten tegen deze inkapseling en de politieke praktijk die dat nastreeft. Daarmee krijgen specifieke lokale organisatievormen van de dorpssamenlevingen de aandacht die ze verdienen. Deze organisatievormen zijn de basis van het referentiekader van de actoren die geconfronteerd worden met het hegemonisch streven van de regimes. Teneinde een zo volledig mogelijk beeld te krijgen van dit proces van inkapseling is een historische analyse noodzakelijk, te beginnen met een beschrijving van deze organisatievormen.

De focus van dit artikel zal dan ook een historische beschouwing zijn over de evolutie van grondbeheer. Dit is de spil waar omheen de Diolasamenleving is georganiseerd en tevens een terrein waarop het hegemonisch streven van de Senegalese staat plaatsvindt. Tevens zal ik verwijzen naar een specifiek Senegalees fenomeen binnen de politieke arena, te weten de factiestrijd binnen de regerende en oppermachtige Parti Socialiste (PS) en zal ik de gevolgen hiervan schetsen voor de regio Ziguinchor waar de Diola de belangrijkste etnische groepering vormen (3).

Welke rol deze factiestrijd uiteindelijk in de regio Ziguinchor zal spelen komt in paragraaf 4 aan bod.

Allereerst wil ik een beschrijving geven van de Diolasamenleving in het prekoloniale tijdperk waarbij ik de nadruk leg op twee cruciale tegenstellingen binnen de produktiewijze bij de Diola. 
Vervolgens schenk ik in de 3e paragraaf aandacht aan transformaties die deze interne tegenstellingen binnen de Diolasamenleving ondergaan door invloeden van buiten. Hierbij behandel ik de voor Senegal toch specifieke aspecten van de Diolasamenleving, namelijk een combinatie van gefragmenteerd leiderschap waarin "verwantschap" een grote rol speelt en het alles overheersende belang van het grondbeheer. Dat laatste is voor dit deel van het Afrikaanse continent, waar zwerflandbouw de regel is en grond van weinig emotioneel belang is en geen hoge gebruikswaarde heeft, een uitzonderlijke situatie.

In de vierde paragraaf wordt de periode na de onafhankelijkheid behandeld. Partijpolitieke belangen van de vanuit Dakar - en door de Diola steevast als 'noorderlingen' bestempelde landgenoten - gedirigeerde politieke partijen, met de PS voorop, bepalen de conflicten rond grondenrechten. Oude gezagsverhoudingen bij de Diola worden hiermee rigoureus terzijde geschoven hetgeen heeft geleid tot een reveil van etnische waarden.

\section{De Pre-koloniale periode}

\subsection{De regio Ziguinchor}

Senegal is administratief opgedeeld in 10 bestuurlijke eenheden, regio's genoemd, met aan het hoofd een gouverneur. De regio Ziguinchor ligt in het uiterste zuidwesten van Senegal en beslaat $7.665 \mathrm{~km}^{2}$. Volgens de volkstelling van 1988 wonen hier 390.252 mensen van verschillende herkomst. De Diola, met 266.000 de numeriek belangrijkste etnische groepering in de regio, vertegenwoordigen $7 \%$ van de Senegalese bevolking. De naam Diola stamt eigenlijk uit de koloniale periode en staat voor een conglomeraat van rijstverbouwende groeperingen, die ondanks opvallend linguïstische verschillen, grote culturele, historische en socio-economische overeenkomsten vertonen. Zo komen diverse auteurs tot een grote verscheidenheid van bevolkingsgroepen die zij onder de paraplu van de term Diola menen te kunnen groeperen:

"... plusieurs essais de classement des populations Joola furent élaborés. Bérenger-Féraud releva l'existance de neuf groupes Joola et Maclaud au début du $\mathrm{XXe}$ siècle en énuméra dix. Plus récemment, L.V.Thomas, s'appuyant sur des considérations anthropologiques et historiques, a proposé le classement suivant: Sur la rive gauche de la Casamance, les Flup autour d'Usuy, les Jamat, appelés autrefois Ayamat autour des villages d'Efok et de Yutu, les Joola-Haer dont le 
centre principal est Kabrouse, les Joola de Jembering, ceux de la Pointe Saint-Georges (les Banjars de Hecquard), le groupe de Brin-Seleki et les Bayot.

Sur la rive droite, Thomas compte neuf groupes mais il prefere donner une classification plus simple et distinguée les Blis-Karone à l'ouest et les Joola du Fooni à l'est' (Roche, 1973: 29).

Het landschap in de regio Ziguinchor wordt bepaald door uitgestrekte waterwegen en mangrovevegetaties, die tezamen het mondingsgebied vormen van de brede Casamance-rivier die de streek doormidden snijdt. Deze specifieke omstandigheden zorgen ervoor dat de Dioladorpen moeilijk bereikbaar zijn, waardoor ze een langdurig geisoleerd bestaan hebben gekend. De Dioladorpen zijn tamelijk groot (van 500 tot wel 7000 inwoners) en zowel politiek als economisch en religieus sterk autonoom. De Diola kennen dan ook geen politieke, religieuze of economische organisatievorm boven het dorpsniveau. Het endogame karakter van de dorpen zorgt er nog eens extra voor dat voor de "pacificatie" van het gebied, de contacten tussen dorpen zeer beperkt zijn en als ze al voorkomen zijn ze vaak vijandig van aard. De inzet van de strijd bestaat dan meestal uit vee, het bemachtigen van krijgsgevangenen die later geruild kunnen worden tegen vee, en de zeggenschap over rijstvelden (vd. Klei, 1982: 61 ev; Roche, 1973: 33 ev; Pelissier, 1966: 673 ev.).

De jaarlijkse regenval van gemiddeld $1200 \mathrm{~mm}$ in de maanden juli tot oktober maakt een intensieve, natte rijstbouw mogelijk aan de boorden van de vele kreken en zijarmen van de Casamance. De zouttong in de Casamance kan tot zo'n $200 \mathrm{~km}$ landinwaarts oprukken en de grote hoeveelheid neerslag tijdens het regenseizoen is nodig om de vruchtbare rijstvelden op de lager gelegen gronden te ontzilten. De Diola kennen een sterk sedentaire landbouwtraditie rond de verbouw van rijst, die volgens deskundigen eeuwen oud is. De beste rijstvelden liggen op de laag gelegen gronden en worden al eeuwen op dezelfde wijze onderhouden: met een lange platte schep, de 'kayendo', wordt de dikke, vette klei omgewoeld en worden de ontelbare dijkjes opgehoogd. Deze velden zijn niet in overvloed aanwezig en de daarbij gevoegde grote hoeveelheid arbeidskracht die het onderhoud vergt, zorgt voor een hoge gebruikswaarde in vergelijking met de in Afrika veel voorkomende kap- en brandlandbouw.

Deze hoge gebruikswaarde verklaart onder andere de autoriteit die ontleend kan worden aan de zeggenschap over deze gronden. Een analyse van de dynamiek van lokale beheersvormen over grond kan het beste deze rijstvelden als focus hebben omdat deze hier het meest manifest is (Pelissier, 1966: 689). De wetenschap dat vele generaties hun arbeid in de grond hebben geïnvesteerd, geeft nog een extra 


\section{SE N E G A}

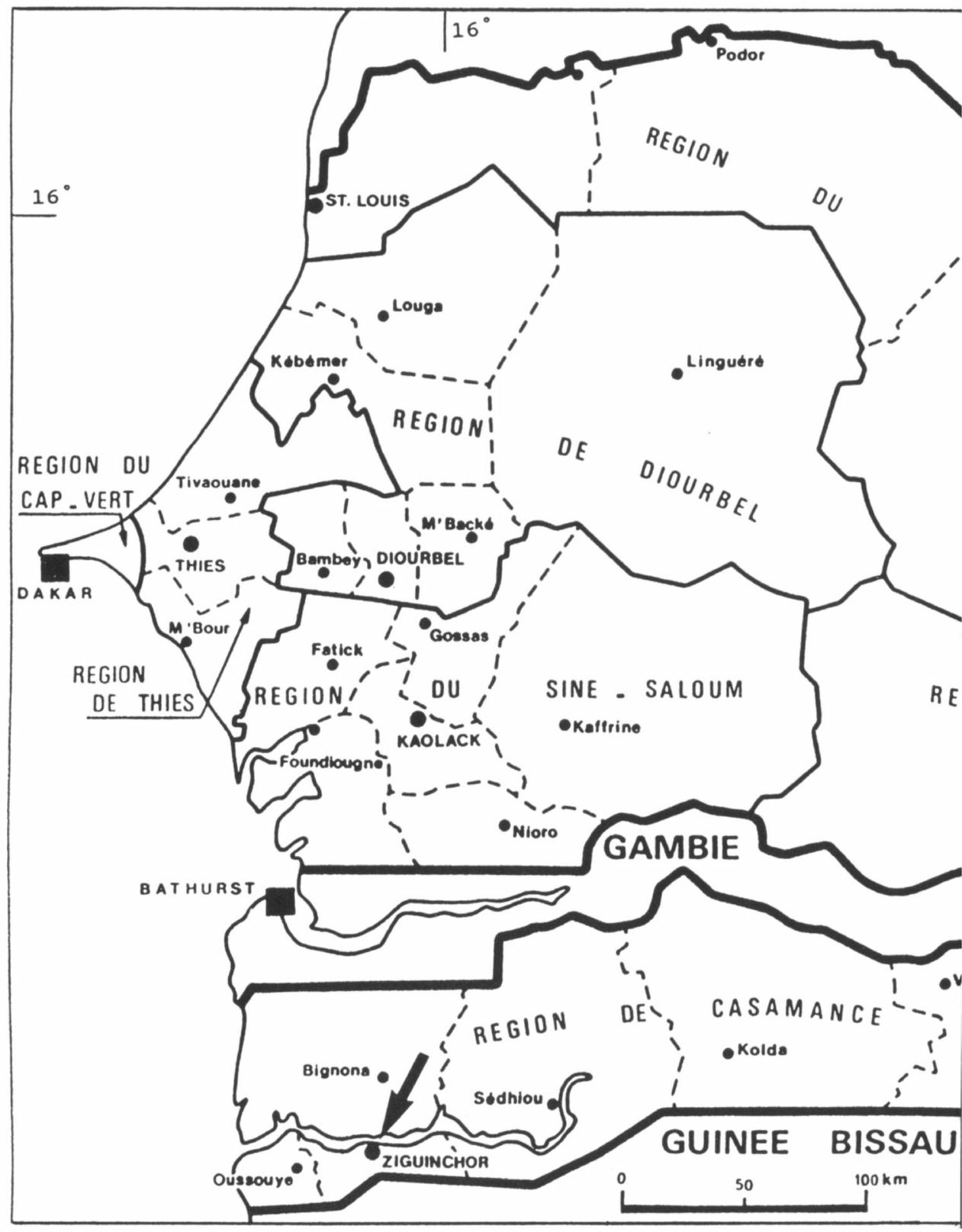




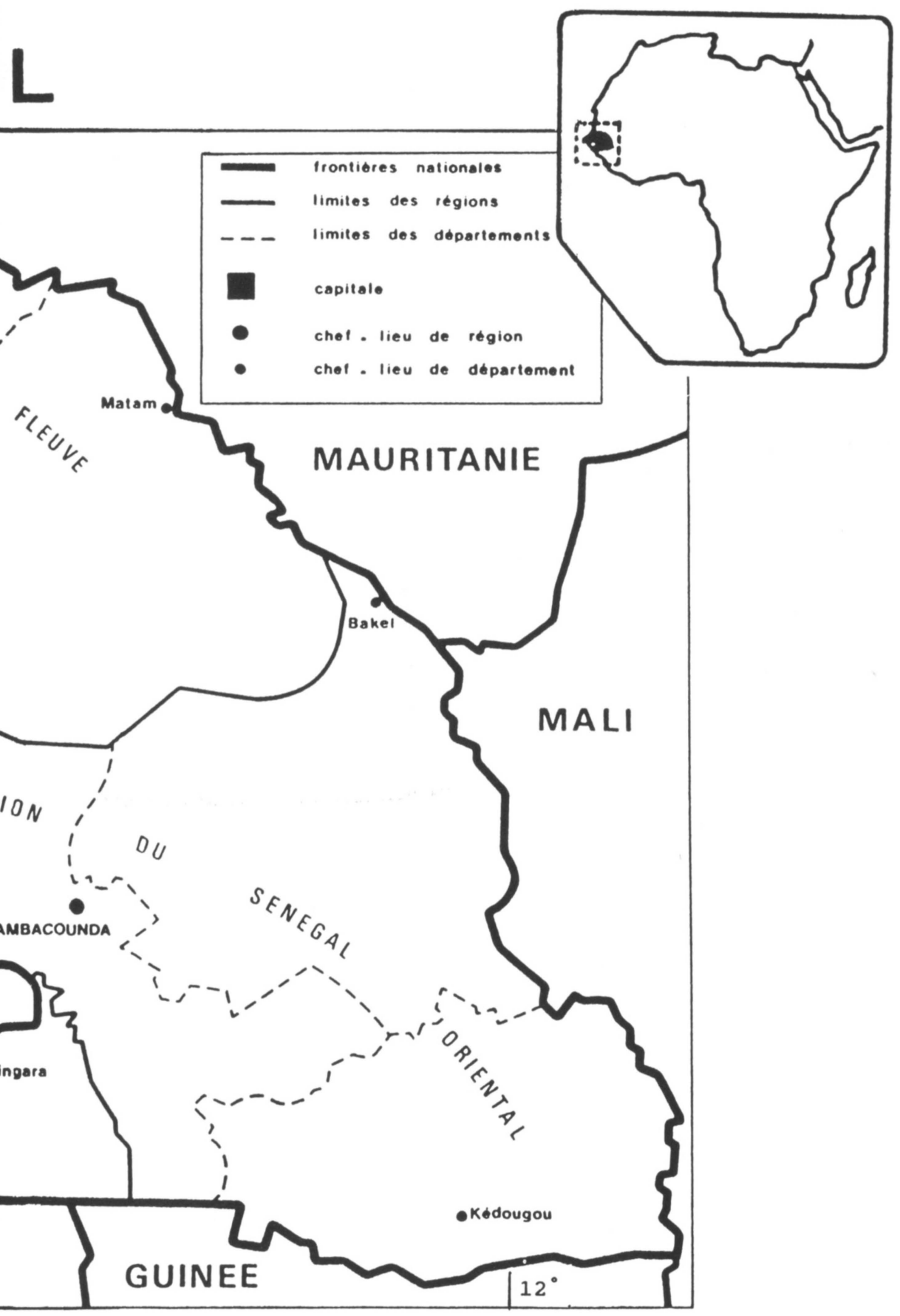


dimensie aan de gebruikswaarde. Dit uit zich in een sterke verbondenheid van de Diola met hun land, hetgeen mede bepalend is voor hun houding ten opzichte van andere bevolkingsgroepen:

"Il n'est qu'un groupe ethnique qui se declare plus ancien qu'eux (les Diola, J.L.E)..., ce sont les Bainouck. Tous les autres: Manding, Mandjak, Mancagne, Wolof, Peul, se savent étrangers, parfois immigrés de très fraîche date. La notion d'autochtones appliquée aux Bainouck et aux Diola et celle d'immigrants appliqué à tous les autres, pour conventionelle qu'elle apparaisse aujourd'hui, recouvrirait une double réalité, d'une part l'importance numérique relative des groupes humains, d'autre part la conscience que ceux-ci eprouvent -et traduisent géographiquement par la prise de possession et l'aménagement du sol -d'être ici chez eux depuis des temps très reculés ou d'être des étrangers infiltrés depuis peu' (Pelissier, 1966: 651).

Deze duidelijke, gevoelsmatige scheiding tussen autochtonen en nieuwkomers (zowel binnen als buiten de etnische groep) speelt een belangrijke rol in het organisatiepatroon van de Diola. Zeggenschap over de belangrijke rijstvelden, alsmede over het vestigingspatroon van nieuwkomers, bepaalt de tegenstelling autochtonen versus allochtonen, waarbij de allochtonen in alle opzichten (ook religieus en politiek) de mindere zijn van de autochtonen. Binnen de Diolasamenleving kan deze veel omvattende tegenstelling samengevat worden met de term Adjiatisysteem.

\subsection{Organisatievormen bij de Diola}

Om het Adjiatisysteem te begrijpen wil ik twee tegenstellingen presenteren, die de spil vormen van de organisatiepatronen bij de Diola en dus de focus dienen te zijn van mijn (historische) analyse van de Diolasamenleving. Deze twee tegenstellingen zijn:

* 1.- de tegenstelling oudsten-jongeren,

* 2.- en de eerder genoemde tegenstelling autochtonen-allochtonen.

2.2.1.: "oudsten" en "jongeren" moeten begrepen worden, niet als biologische maar als sociale categorieën: "oudste" is alleen diegene die afhankelijken (jongere verwanten, ingetrouwde vrouwen, cliënten) om zich heen verzamelt, terwijl de categorie "jongeren" ook vrouwen omvat (Geschiere, 1985: 339). Hiermee is uiteraard niet alles gezegd over de plaats van vrouwen in de Diolasamenleving; 
vrouwen vervullen een essentiële complementaire functie binnen het productieproces. Het voert echter te ver in het kader van mijn betoog hier verder op in te gaan.

Bij de Diola is het gezag van de oudste op twee zaken gebaseerd: enerzijds de controle over het produktiemiddel land (vooral de "schaarse" rijstvelden), anderzijds de zeggenschap over personen, met name de circulatie van arbeidskrachten - vrouwen en jongeren - tussen de produktiegemeenschappen. Vooral de zeggenschap over jonge vrouwen is van cruciaal belang: jonge mannen zijn van de oudsten afhankelijk om aan een vrouw te komen teneinde op hun beurt in staat te zijn zich te reproduceren.

Binnen deze reproductiecyclus spelen "prestige goederen" een centrale rol. Voordat jonge mannen kunnen trouwen, dienen zij eerst de initiatieriten te doorlopen. Deze vinden eens in de twintig tot dertig jaar plaats in het belangrijkste heiligdom van het dorp, de Kareng. Tijdens deze initiatieriten (in Diola: Bukut) wordt op grote schaal het prestigemiddel bij uitstek, te weten vee, vernietigd. Alleen de oudsten kunnen het surplus van de rijstoogst, afkomstig van de rijstvelden van de patrilinies waar zij de zeggenschap over hebben, ruilen tegen vee. Met de tijdsbepaling van de Bukut hebben de oudsten ook nog eens zeggenschap over het moment waarop jongeren kunnen trouwen om daarna aanspraak te kunnen maken op rijstland van de patrilinie. Ook bij de toewijzing van rijstland zijn jongeren weer afhankelijk van de oudsten.

2.2.2.: Het belang van leeftijd, oftewel het primaat van de eerstgekomene, komen we bij de Diola ook tegen in het vestigingspatroon: er wordt een duidelijk onderscheid gemaakt tussen autochtonen en allochtonen.

De macht van de oudsten over jongeren is niet alleen gebaseerd op het feit dat de oudsten het "schaarse" rijstland en de huwbare vrouwen monopoliseren, maar ook op de animistische religie van voorouderverering. Deze laatste machtsbasis wordt ook duidelijk in de hiërarchie tussen oude families en zij die later zijn gekomen in een dorp, ofwel tussen autochtonen en allochtonen. Meestal bestaat een dorp uit meerdere patrilinies. Elke patrilinie heeft haar eigen rijstvelden, bewoont een duidelijk te onderscheiden gedeelte van het dorp (wijk) en elke wijk heeft zijn eigen heiligdom. Het heiligdom van de eerstgekomen linie - beheerd door de linie-oudste van deze patrilinie - is het belangrijkste dorpsheiligdom. Dit dorpsheiligdom, Kareng, is vaak niet veel meer dan een dicht bebost gedeelte rondom een grote, oude boom. Hier vinden de initiatieriten van alle jonge mannen uit het dorp plaats alsook de vaak geheime politieke vergaderingen die bijgewoond worden door alle geïnitieerde linieleden. De initiatieriten voor jonge mannen vinden én keer in de 
twintig jaar plaats en allen, ook zij die buiten het dorp verblijven, dienen die te ondergaan.

De specifieke vorm van grondbeheer onder de Diola vormt de voornaamste basis van de tegenstelling autochtonen versus allochtonen. Het beheer van de rijstveldendie zoals ik eerder heb vermeld een constante waarde hebben- door de autochtone linie-oudsten leidt tot een patroon van afhankelijkheidsrelaties met als middelpunt de linie- oudste. Deze kan optreden als landvoogd van de familiegronden en de nieuwkomer land in bruikleen geven. Een oudste die aldus als voogd optreedt wordt door de Diola adjiati genoemd, een term die is afgeleid van het woord "vader". Door de specifieke complexiteit van de afhankelijkheidsrelaties die hij om zich heen weeft, prefereer ik de term adjiatisysteem boven begrippen als patroon-cliënt relatie of voogdijschap.

In de praktijk gaat een nieuwkomer in een dorp op zoek naar een linie-oudste die in staat én bereid is de immigrant het gebruiksrecht over een perceel te verlenen. Heeft de immigrant zo'n linie-oudste gevonden, dan is het de gewoonte dat hij eerst een tijd bij deze voogd of adjiati inwoont tot hij in zijn eigen levensonderhoud kan voorzien: dus tot de eerste oogst van zijn "geleende" perceel is binnengehaald.

"In de eerste plaats is de adjiati een gastheer die een immigrant voor korte of langere tijd in zijn huis opneemt en van voedsel en onderdak voorziet. De logé of adjaoura (letterlijk 'vreemdeling') vindt bij zijn adjiati een eerste onderkomen én een ingang in de samenleving waarin hij zich wil vestigen; hij ziet zijn eerste levensbehoeften bevredigd en vindt tevens een basis van waaruit hij zijn nieuwe woonplaats en haar mogelijkheden kan leren kennen. Vervolgens zorgt de adjiati ervoor, dat zijn gast zich zelfstandig kan vestigen: hij geeft hem een stuk land of brengt hem in contact met iemand die hem aan land kan helpen; zo kan de adjiati zelf grondvoogd zijn ofwel middelaar ('middle man') tussen nieuwkomer en grondvoogd.

In ruil voor opvang, bemiddeling en land, erkent de adjaoura zijn adjiati als een autoriteit, als een soort vader- de relatie tussen adjiati en een adjaoura wordt vaak in verwantschappelijke termen aangeduid -als zijn meerdere op religieus, politiek en economisch gebied" (van der Drift, 1985: 22).

Ook het ontstaan van de zogenaamde latere 'spontane' woonwijken in de urbane centra verloopt grotendeels volgens bovenstaande principes. Het gevolg hiervan is dat deze 'spontane' wijken niet zo anarchistisch of spontaan zijn als vaak door de stedelijke overheden wordt beweerd. Zij kennen wel degelijk een duidelijke organisatievorm met een geheel eigen dynamiek, waarbij grondbeheer een centrale 
rol vervult (zie Eichelsheim, 1986). De bewoners ervaren hun niet door de overheid erkende vestigingsplek als een plaats met een zekere mate van woonzekerheid. Zij worden immers 'beschermd' door hun adjiati, waaraan zij de nodige verplichtingen hebben vervuld of nog steeds vervullen. Dat de grondvoogden in de steden de laatste jaren steeds meer zijn overgegaan tot het verdelen van hun grondbezit in kavels en die voor redelijke bedragen verkopen doet hier niets aan af.

\section{Schaalvergroting tijdens de koloniale periode in Casa- mance: de eerste voorzichtige politisering van lokale organisatievormen}

Na de Conferentie van Berlijn (1884-1885) werd een groot gedeelte van West-Afrika aan de Fransen toegewezen. Enkele andere Europese staten behielden stukken land langs belangrijke grote rivieren: een strook langs de rivier Gambia bleef in Engelse handen, terwijl het gebied rondom de mondingen van de Rio Cacheu en de Rio Geba in Portugese handen bleef, alsmede de Kaap-Verdische eilanden. Deze kunstmatige verdeling van Afrika door de diverse koloniale mogendheden speelt ook in de huidige republiek Senegal nog een grote rol: de Casamance streek ligt ingeklemd tussen Gambia en Guinee-Bissau. Dit geldt vooral voor het westelijke gedeelte van Casamance, voorheen bekend als Basse-Casamance en sinds 1984 de huidige regio Ziguinchor, waarvan de directe verbindingen met de metropool Dakar worden onderbroken door de Engelstalige republiek Gambia. Klimatologisch vertoont Casamance (dat valt onder de Soudano-Guinese klimaatzone in tegenstelling tot de rest van Senegal dat onder de invloed ligt van het veel drogere Sahel klimaat) grote overeenkomsten met de buurlanden Gambia en Guinee-Bissau. Zowel economisch als cultureel en linguïstiek bestaan er, ook na de onafhankelijkheid, sterke banden met deze buren. Nog steeds hebben de autochtonen van Casamance weinig solidariteitsgevoel met hun landgenoten die boven de Gambia-rivier wonen.

Onder het Franse bewind werd in noordoost-Senegal al snel de aardnoot als cashcrop geïntroduceerd. Mede door de steun van machtige marabouts van de diverse Islamitische broederschappen, met name de Mouriden, nam de aardnootproduktie al snel een voorname plaats in als belangrijkste exportartikel. In Casamance bleef de aanwezigheid van de koloniale machthebbers lang onopgemerkt. De Dioladorpen in het moeilijk toegankelijke gebied kwamen pas rond 1917 onder staatscontrole en vanaf die tijd was reizen in Casamance voor het eerst echt moge- 
lijk. Al snel na de 'pacificatie' van het gebied ontwikkelde zich arbeidsmigratie van Diola-jongeren naar gebieden met marktgewassen, met Gambia als voornaamste trekpleister (vd. Klei, 1977 en 1985). In de dertiger jaren werd de aardnoot als marktgewas in Casamance geïntroduceerd. Bestond er voor die tijd nog een surplus- produktie van rijst dat met Mandengue-handelaren werd geruild tegen vee, het prestigegoed bij uitstek, na de intrede van het marktgewas aardnoot is de rijstopbrengst alleen gebruikt voor autoconsumptie (4).

Het besef dat Senegal teveel leunde op de monocultuur van de aardnoot is pas laat doorgedrongen. Pas na de 2e Wereldoorlog en het begin van de oorlog in Indochina aan het eind van de veertiger jaren werd het Franse koloniale bestuur met de neus op de feiten gedrukt toen de rijstimporten vanuit Indochina steeds onzekerder werden, terwijl de vraag alsmaar steeg: in 1944 werd nog 50.000 ton rijst ingevoerd, maar in 1959 was dat al 135.000 ton. Hoeveel geld met deze importen was gemoeid blijkt uit de cijfers over de periode 1961-65 (138.481 ton rijst geïmporteerd tegen een waarde van 3,5 miljard F CFA) en 1971-74 toen er 181.086 ton werd ingevoerd tegen een waarde van 8,5 miljard F CFA (Carvalho, 1983: 152 ev.) (5).

In 1946 startte de kolonisator het eerste grootschalige en gemechaniseerde rijstbouwproject waarmee men tegemoet hoopte te komen aan de binnenlandse vraag. Dit eerste project was gesitueerd bij Richard Toll, in de Fleuve-regio. Pas in 1954 werden de eerste voorzichtige stappen in Casamance gezet en wel door de Compagnie Générale des Oléagineux Tropicaux (CGOT) die rond Sedhiou met de mechanische verbouw van rijst begon. Pas in 1962 zag de Senegalese staat het werkelijke potentieel van Casamance als graanschuur in. Ze richtte de Société de Développement Agricole et Industrièle de la Casamance (SODAICA) op en er werden Franse en Nederlandse adviesbureaus uitgenodigd om onderzoek te verrichten.

Hieruit kunnen we concluderen dat de meest voor de hand liggende lokatie om een rijstproject te starten, namelijk in Casamance (6), pas zeer laat aan bod kwam. Debet hieraan was het gebrek aan invloedrijke regiovertegenwoordigers van Casamance in de metropool Dakar. Al werd ze steeds meer gezien als de (toekomstige) graanschuur, de investeringen of andere initiatieven om de rijstproduktie te stimuleren bleven voorlopig achterwege. In tegendeel, zo leidde een verhoging van de belasting tussen 1918 en 1920 van 5 naar 10 Francs en een toenemende monetarisering van prestigegoederen (7) tot verhoogde migratie naar Gambia en werd met de komst van scholen steeds meer arbeid aan de rijstvelden onttrokken (Hamer, 1981: 190 ev. zie ook vd. Klei, 1978 en 1985). Waar in Noord-Senegal religieuze leiders hun economische sleutelpositie zagen beloond met 
invloedrijke posities binnen het machtscentrum Dakar en daardoor weer in staat waren om geldstromen hun regio binnen te sluizen, ontbrak het in Casamance aan representatief leiderschap om dit te verwezenlijken.

In het eerste gedeelte van dit artikel heb ik opgemerkt dat het organisatiepatroon bij de Diola van oudsher werd gekenmerkt door een weinig hiërarchische structuur boven het dorpsniveau. In mindere mate geldt dit nog steeds. Vandaag de dag komen we ook beperkte vormen van organisatiestructuren tegen op regionaal niveau en kunnen we zelfs van pan-Diola instituten spreken. Het fundament van de overgang van kleinschalig en geografisch vaak zeer beperkt leiderschap naar grotere organisatievormen werd gelegd door schaalvergroting als gevolg van (seizoensgebonden) migratie en scholing buiten de dorpsgemeenschap. Oude organisatievormen binnen de dorpssamenleving, zoals leeftijdsgroepen onder jongeren, kregen vooral onder studenten in Parijs en Dakar een meer regionaal en etnisch karakter (zie Coquery-Vidrovitch, 1985: 76). Als wij-groep zette men zich af tegen andere etnische groeperingen die de grote steden bevolkten. Onvrede met de politieke koers in Senegal van de toenmalige politieke leiders leidde ertoe dat dit soort groepen van studenten en uit Parijs teruggekeerde afgestudeerden zeer kritisch stonden tegenover de lokale machthebbers.

Eind vijftiger jaren richtten jonge intellectuelen uit Casamance in Dakar een overkoepelend genootschap op: de Rassemblement des Associations de Boulouf (R.A.B.). Dit genootschap groepeerde nog maar een klein gedeelte van de bewoners van Casamance, namelijk die van de streek Boulouf, maar de schaalvergroting zou snel doorzetten. De R.A.B. organiseerde in Dakar feesten en andere bijeenkomsten die druk bezocht werden door migranten uit deze streek. Met het geld dat hiermee werd ingezameld konden andere groepsactiviteiten georganiseerd worden. Het succes in Dakar leidde tot het inzicht dat deze feesten ook een goede bron van inkomsten konden vormen voor de dorpen. Een kleine geldstroom richting geboortedorpen kwam op gang en men begon in de dorpen ook zelf balavonden te organiseren. Met het binnenkomend geld werd de infrastructuur verbeterd en een nieuw genootschap zag het daglicht. Deze noemde zich Bouloudji (Boulouf ontwaakt!) en voor het eerst werd er druk uitgeoefend op de lokale overheden voor meer investeringen in de regio. Dit soort genootschappen werden echter niet erkend door de overheid omdat zij een etnisch reveil niet wilde stimuleren. Volgens de grondwet waren louter op etnische afkomst gebaseerde instituten verboden naar aanleiding van negatieve ervaringen met dit soort instituten in de metropool Dakar.

Toch slaagden enkele politici uit Casamance er in om zich in de tumultueuze periode van vlak voor de onafhankelijkheid te scharen onder één banier, al voert die dan de kleuren van regionale onafhankelijkheid. Zo komen we de naam 
Mouvement des Forces Démocratiques de Casamance (MFDC) in de landelijke politiek voor het eerst tegen tijdens de verkiezingen voor de Franse Assemblée op 17 juni 1951. Léopold Sédar Senghor had op 27 oktober 1948 een nieuwe politieke partij opgericht, de Bloc Démocratique Sénégalais (BDS), die zich onafhankelijk van de Franse socialistische partij zou opstellen en een federalistische koers zou gaan varen. Senghor zocht en vond (geheel conform de bekende verdeel- en heerspolitiek) steun bij religieuze en lokale leiders en de wijze waarop de BDS was geformeerd zou de latere Senegalese politiek bepalen, waarin onderhandelingen en cliëntisme een centrale rol gingen spelen:

"... le Bloc Démocratique s'est attaché une très large part de ses militants, non par adhésion individuelle, mais à la suite de négociations avec les chefs de groupes ethniques ou de notables réligieux. Il a utilisé à son profit toutes les formes de regroupement qui se sont substitués au clan familial depuis le début de la colonisation. Ralliant le responsable de chacun de ces groupes, il obtenait l'adhésion de la totalité des membres du groupe..."(Zuccarelli, 1970: 47).

Zo kwam bij verkiezingen in 1956 het dichtbevolkte Sine-Saloum in handen van de BDS omdat de plaatselijke leider Ibrahima Seydou N'Dao de Senegalese afdeling van de Franse socialistische partij, de SFIO (Section Francaise de l'Internationale Ouvrière) geleid door de jurist Lamine Gueye, verliet en overstapte naar Senghor (Zuccarelli, 1970: 48). In Casamance, waar het leiderschap vergeleken met de rest van Senegal nog zeer kleinschalig was, stootte de verdeel- en heerspolitiek van Senghor op een veelheid van belangengroepjes waardoor de BDS nooit een hechte basis kon veroveren. Zo verliet in 1954 een andere belangrijke regionale machtsgroep, de Mouvement Autonome de la Casamance (MAC) onder leiderschap van Assane Seck, de BDS en daarna volgde voor Casamance een verwarrende periode van fusies tussen lokale en landelijke machtsblokken die geformeerd werden of uiteen vielen. De BDS werd Bloc Populaire Sénégalais (BPS) en in 1958 uiteindelijk Union Progressiste Sénégalais (UPS) waarmee Senghor de onafhankelijkheid inging. Ook na de onafhankelijkheid was de Senegalese politiek volop in beweging. Toch kende deze periode twee konstanten: een enorme machtsconcentratie in de gedaante van de UPS (vanaf 27/12/1976 Parti Socialiste) en de voortdurende kritiek op het beleid van dit machtsblok vanuit met name Casamance, waar sterke regionale gevoelens heersten (Zuccarelli, 1970: 130).

Het lukte Senghor echter steeds meer om belangrijke Diolaleiders binnen zijn partij te halen door hen overheidsposten aan te bieden. Deze zich in de landelijke politieke arena bewegende Diola-politici waren afhankelijk van kleinere politieke voormannen wier machtsbasis vaak niet uitsteeg boven het dorpsniveau. Dit bleek een sterk fluctuerende achterban met weinig affiniteit voor de landelijke politiek. 
Zij schaarden zich achter die politici die bereid waren te investeren in hun 'dorpssamenleving'. Gevolg was een voortdurende strijd tussen landelijke politici onderling om de gunsten van deze achterban. Deze strijd speelde zich af tussen UPS/PS politici onderling, maar ook met leden van de oppositie (8). Politieke leiders waren niet echt honkvast en wisselden, naar gelang de hen geboden vooruitzichten, nogal eens van partij.

\section{Het postkoloniale tijdperk}

\subsection{Ontwikkelingsprojecten en lokale machtsverhoudin- gen in Casamance}

$\mathrm{Na}$ de onafhankelijkheid op 21 augustus 1960 werden de beleidsmaatregelen voor economische ontwikkeling vastgelegd in vier-jarenplannen. Hiermee poogde de staat meer greep te krijgen op de economische ontwikkeling van het land en de smalle basis van de monocultuur van de aardnoot te verbreden. De Fleuveregio en de Casamanceregio werden aangewezen als gebieden die voor een rijstsurplus moesten gaan zorgen waarmee aan de vraag uit de steden en het aardnootbekken kon worden voldaan. Volgens de Franse adviesbureaus zat achter deze spreiding nog een tweede voordeel: zij gingen er namelijk van uit dat economische isolatie gekoppeld is aan een marginale positie op het sociaal-culturele vlak. Stimulering van de rijstbouw in Casamance zou binnen deze zienswijze dan ook leiden tot opheffing van de economische isolatie en dus ook van de marginale sociaal-culturele positie.

Overheidsgelden voor binnenlandse investeringen waren echter zeer schaars en kwamen slechts zelden boven de $21 \%$ van alle overheidsuitgaven (Carvalho, 1983: $171 \mathrm{ev}$.$) . Op dit bescheiden budget werd ook nog eens een zware claim gelegd$ door de diverse ministers, politici en traditionele notabelen:

"in the process of party and power consolidation in the 1960's, and because of the adherence of most of its members to consensual decision-making, government used resources from the capital budget to respond to local interests and particularist demands made by deputies, UPS local leaders, and marabouts' (Carvalho, 1983: 176). 
Het was dan ook niet verwonderlijk dat de meeste investeringen in het economisch belangrijke aardnootbekken en de dichtbevolkte regio's van Cap-Vert en Sine-Saloum belandden en zeker niet in een gebied dat een veel lagere bevolkingsdichtheid kende (en politiek dus minder machtig was) en waar ook nog eens een op zelfvoorziening gerichte landbouw plaatsvond. Investeringen in de rijstbouw in Casamance waren dan ook in grote mate afhankelijk van buitenlandse hulp. Uit documenten van het ministerie van Planning $(1967,1977)$, het Franse Fonds d'Aide et de Coopération (FAC, 1961) en de European Development Fund (EDF, 1981) bleek dat $69 \%$ van de gelden die werden geïnvesteerd in de rijstbouw in Casamance afkomstig waren van FAC, EDF, Nederland, World Bank en USAID (Carvalho, 1983: 171).

Ook deze buitenlandse donors hadden veel hinder van de factiestrijd binnen de PS, die vooral in Casamance werd gekenmerkt door een grote felheid. Volgens twee Nederlandse stafleden van het ILACO- rijstproject in de buurt van Ziguinchor, hadden lokale UPS-politici eind zestiger jaren gezorgd voor een spreiding van investeringen naar dorpen waar hun grootste achterban was gevestigd. Vooral rond verkiezingstijd werden investeringen toegezegd. Daarna werd grote druk uitgeoefend om deze investeringen te verwezenlijken, hetgeen vaak indruiste tegen de doelmatigheid van lopende projecten. In dit verband werden nogal eens de namen genoemd van Louis Dacosta, Robert Sagna en vooral Mamadou Abdoulaye Sy, die begin jaren tachtig burgemeester van Ziguinchor was geworden (Carvalho, 1983: 180). De evolutie van deze factiestrijd in Casamance zal in het volgende deel aan bod komen.

In haar hegemonisch streven werd Dakar gedwongen steeds meer aandacht aan de onrustige zuidelijke regio te schenken. Daar groeide de oppositie tegen het 'noordelijke kolonialisme' door een ontluiken van een pan-Diola identiteit. Dit etnisch reveil geraakte begin zeventiger jaren in een stroomversnelling door enkele externe factoren: grootschalige immigratie van andere etnische groeperingen door droogte in het noorden van Senegal en de burgeroorlog in Guinee Bissau. Een sterk verminderde regenval sinds 1969, vooral merkbaar in het noorden van Senegal leidde tot grootschalige immigratie van Toucouleur-vissers en Peul-herders. De onafhankelijkheidsoorlog in Guinee Bissau, gevoerd door de Partido Africano da Independencia da Guiné e do Cabo Verde (PAIGC) tegen de Portugezen joeg alleen in 1972 al 71.470 mensen over de grens met Senegal (Carvalho, 1983: 211). Grensoverschrijdingen leidden tot een hoge concentratie van Senegalese troepen in Casamance. Bij schermutselingen vielen ook slachtoffers in Dioladorpen hetgeen, samen met de affiniteitsgevoelens voor de vrijheidsoorlog in het buurland, de aversie tegen dit noordelijke 'bezettingsleger' vergrootte. Temeer toen dit leger 
werd ingezet tijdens onlusten die uitbraken rond de grondonteigening voor het hotelcomplex Club Méditerranée bij het dorp Diakene-Diola in 1972.

Teneinde deze gevoelens van aversie tegen Dakar te kunnen kanaliseren - hetgeen binnen de politieke arena niet mogelijk bleek - besloot de regering een nieuw genootschap te erkennen dat werd geleid door veelal oude, gematigde Diolamannen die in de koloniale tijd ambtelijke functies hadden vervuld. Het nieuwe genootschap kreeg de naam Karambenor (Diola voor onderlinge of wederzijdse hulp). Met deze stap poogde de staat oude organisatiestructuren bij de Diola te politiseren en zodoende greep te krijgen op de Diolasamenleving. Ook nu weer dacht de staat via enkele Diola-voormannen de gehele samenleving te kunnen controleren. Niets was echter minder waar. Al kon de Karambenór gezien worden als eerste verschijning van een pan-Diola organisatie, het leiderschap bleef fragmentarisch. Analoog aan oude organisatiepatronen binnen de Diolasamenleving werd het leiderschap omgeven door antagonistische bewegingen. Waarmee ik wil zeggen dat het fenomeen factiestrijd, zo kenmerkend voor de Senegalese politiek, voor de Diola zeer herkenbaar was omdat het historisch lag ingebed binnen hun oude organisatievormen. Tegen deze achtergrond zal ik in de volgende paragraaf een tweede vorm van staatsinterventie behandelen.

\section{2.- De (her)verkaveling als casus van staatspenetratie}

De stad Ziguinchor was in goed zestig jaar uitgegroeid van een klein vissersdorp, met 1300 inwoners in 1921, tot een middelgrote regionale hoofdstad met meer dan 100000 inwoners. Het groeicijfer schommelde tussen de 4,5 en $7 \%$, waarvan de helft werd veroorzaakt door immigratie (Bruneau, 1979: 109 en Plan Directeur, 1982). Sinds jaren werd deze aanwas opgevangen zonder noemenswaardige bemoeienissen van de stedelijke overheden: alleen in 1952 en 1972 waren enkele kleinschalige verkavelingsprojecten uitgevoerd. Als gevolg van de toename van de bevolking en de naar verhouding geringe uitbreiding van het door de overheid verkavelde gebied werden de personen, die een zelfstandige vestiging verkozen, gedwongen om in de stedelijke periferie een woonplek te zoeken. Vaak beschikte de overheid niet over voldoende middelen om de ruimtelijke herinrichting van deze woonzones uit te voeren.

In 1964 kwam in Senegal op nationaal niveau de "Loi sur le Domaine National" tot stand, die een verregaande landhervorming behelste. De staat werd beheerder of landvoogd van bijna $90 \%$ van het totale grondgebied van de republiek Senegal. Behalve gronden met een geregistreerd eigendomsrecht verviel alle grond onder het "Domaine National". De meeste gronden waarop de uitbreidingen van Ziguinchor 


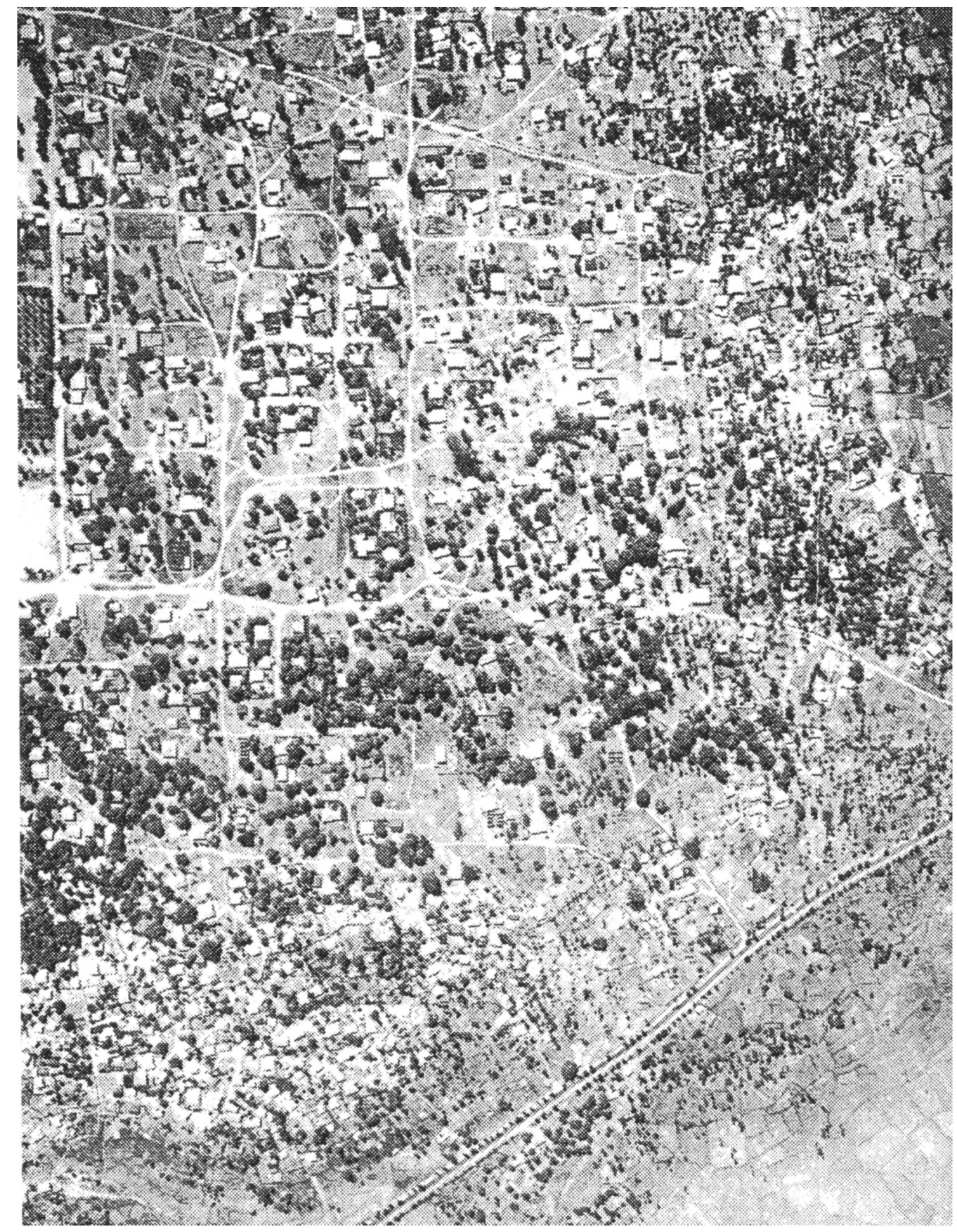

De georganiseerde wanorde van de wijk Lyndiane in Ziguinchor 
plaatsvonden vielen onder dit "Domaine National". Teneinde de wildgroei in de stad enigszins in banen te leiden was in 1969 een structuurplan voor Ziguinchor opgesteld, het Plan d'Urbanisme, dat later in 1973 en 1982 nog was aangepast. Hierin waren de "spontane" woonwijken keurig opgedeeld in kavels, wegen en openbare ruimten volgens het dambord- model. De bedoeling was dat deze "spontane" woonwijken in fasen werden verbeterd: eerst markeerde men de wegen en de terreinen voor openbare voorzieningen in de wijk door het plaatsen van kleine betonnen paaltjes (bornes). De bewoners kregen een jaar de tijd om zich aan deze nieuwe indeling aan te passen, hetgeen inhield dat huizen eventueel verplaatst dienden te worden indien bleek dat ze nu op een weg of openbaar terrein stonden. Daar stond tegenover dat de bewoners nu van de gemeente een bewijs (ticket) kregen dat ze zich konden vestigen op een officieel kavel, waarvan het nummer en de naam van de gebruiker was vastgelegd in het kadaster. Deze tickets werden direct na het plaatsen van de bornes door een toewijzingscommissie aan de wijkbewoners gegeven, zodat ze konden zien welke kavel zij kregen toegewezen (9). Lokale politici van de Parti Socialiste hadden binnen deze toewijzingscommissie een grote vinger in de pap (Eichelsheim, 1986: 53 ev.). Aangezien er zich binnen de PS-fractie in Ziguinchor op dat moment een felle factiestrijd afspeelde, had dit vergaande gevolgen. Factieleiders deden er alles aan om een zo groot mogelijke groep volgelingen achter zich te verzamelen en zodoende de factiestrijd in hun voordeel te beslissen. Elk middel was heilig om dit doel te bereiken. Ook gesjoemel met oude eigendomsrechten van familiegronden.

De strijd om de politieke hegemonie kostte de factieleiders echter zeer veel geld en de gang van zaken rond de herverkaveling bracht hiervoor uitkomst: de bevolkingsdichtheid van de wijken die verkaveld werden was erg laag en de woonpercelen groot. Hierdoor was het mogelijk dat er na de verkaveling kavels overbleven (dit aantal kon nog vergroot worden door politieke opposanten in de wijk geen of minder kavels toe te wijzen dan waar ze recht op hadden). Deze kavels werden weggegeven aan partijvriendjes of verkocht aan belangstellenden. Vooral in Casamance geboren militairen, hogere ambtenaren uit het noorden van Senegal en Casamancais die in Frankrijk of Dakar werkten hadden veel belangstelling voor deze kavels. De prijzen voor zo'n kavel konden in 1983 dan ook oplopen tot én miljoen F CFA of zelfs meer.

Deze herverdeling van grond druiste in tegen het organisatiepatroon van de wijk dat juist grond als bindmiddel had. Analoog aan het organisatiepatroon in de Dioladorpen, zoals beschreven in 2.2., traden linie-oudsten van het naburige Dioladorp op als adjiati voor nieuwkomers die op hun beurt weer zouden gaan optreden als adjiati voor jongere generaties die naar de stad trokken. Op deze wijze werd dorpsgrond opgeslokt door de zich steeds verder uitdijende stad, maar 
eigendomsrechten binnen de nieuwe stadswijk voerden altijd terug naar het dorp en/of oudere wijkbewoners (overeenkomstig de evoluerende machtsverhoudingen binnen de tegenstelling autochtonen - allochtonen in de Dioladorpen, is een adjiati van de eerste generatie belangrijker en machtiger dan een adjiati van volgende generaties). Bemoeiingen van buitenaf, zoals in het geval van herverkaveling door gemeentelijke instanties en gemanipuleerd door lokale politici, kreeg een emotionele lading omdat deze geen rekening hield met voornoemde en voor de direct betrokkenen duidelijk aanwezige organisatievorm van het te verdelen gebied.

Immers de adjiati in de wijk had zijn adjaoura gebruiksrecht gegeven over grond en daarmee, volgens de oude Diola organisatiepatronen, stilzwijgend een overeenkomst gesloten dat hij zijn adjaoura "als zijn eigen kinderen" zou beschermen. De positie van een adjiati werd onhoudbaar op die momenten dat de rollen van adjiati en politiek leider in één persoon samenkwamen.

Deze politisering van het adjiatischap was niet zo vreemd: de adjiati had door mensen gebruiksrecht te verlenen over grond een schare volgelingen achter zich weten te verzamelen. Daarvan was hij volgens de oude tradities ook de politieke autoriteit en zo werd hij voor nationale politieke partijen een gewild figuur. Niet zelden vloeide de functie van Responsable Politique met die van adjiati dan ook in én figuur samen. Wanneer hij in de ogen van zijn adjaoura niet voldeed aan de rolverwachtingen die aan beide rollen kleefden, was hij zijn autoriteit verloren. De kans was groot dat zijn adjaoura zich tegen hem en zijn politieke vriendjes keerden en de 'verwantschappelijke' band tussen adjiati en adjaoura kon ertoe leiden dat dit met veel emoties gepaard kon gaan.

\section{5.- Evaluatie}

De willekeur bij de toewijzing van kavels stuitte zoals valt te verwachten op veel weerstand in de wijken. De protesten konden niet opgelost worden door de van oudsher hiermee belaste figuur, te weten de adjiati, omdat deze zelf tot over zijn oren in de problematiek was verstrikt. Er volgde dan ook een cumulatie van protesten. Dit ging steeds meer gepaard met geweld, dat zich meer en meer richtte tegen de overheid die gezien werd als beschermvrouwe van allochtonen die erop uit waren het land in te pikken. Op advies van lokale notabelen ging de Gouverneur, als hoogste regeringsverantwoordelijke, op zoek naar een vervangende en door de lokale bevolking geaccepteerde rechtsprekende macht. Hij besloot de ergste conflictgevallen rond kaveltoewijzingen te laten evalueren door de pas opgerichte Diola-associatie Karambenor waarvan de leden niet alleen vooraanstaande 
Diolamannen waren, maar door hun verleden ook sterke banden hadden met de overheid.

Van 16 februari 1982 tot 5 juli 1983 heeft de Karambenor 5171 kaveltoewijzingen bekeken en 1558 conflictgevallen (10) opgelost (zie Eichelsheim, 1986: 104). De gevolgde procedure voor het oplossen van conflicten vertoonde sterke overeenkomsten met de oude rechtspraak door de raad van oudsten in Dioladorpen. $\mathrm{Na}$ langdurige palavers ter plaatse rolde er vaak een Salomons oordeel uit dat beide partijen tevreden stelde. Maar al te vaak echter resulteerde deze uitspraak niet tot een fundamentele oplossing van het conflict dat zijn oorsprong meestal vond in oude aanspraken op grond. Zo liet de ontstaansgeschiedenis van een nieuwe woonwijk zien dat nieuwkomers niet zonder hulp van een adjiati, of deze nu van de eerste of tweede generatie was, grond in de wijk kon bemachtigen. Tijdens de herverkaveling werd deze ontstaansdynamiek eenvoudigweg opzij geschoven door gemeentelijke instanties die op hun beurt werden gemanipuleerd door lokale politici van de PS. Zo kon het gebeuren dat grond werd afgepakt zonder dat de plaatselijke adjiati daar tegen kon of wilde ageren. Door het specifieke optreden van de Karambenór, wier oplossing het zoeken naar consensus was vanuit de situatie na de kaveltoewijzing, werd deze bron van het conflict enkel met een laagje zand bedekt. Het valt dan ook te verwachten dat latente aanspraken op stukken grond na verloop van tijd weer de kop op gaan steken. Temeer daar de Karambenór zich steeds meer van haar achterban verwijderde. De haar opgedrongen intermediaire rol bracht haar steeds meer in het kamp van de overheid. Steeds meer werden de leiders van Karambenor voor de kar van de PS gespannen om vervolgens als dolle honden achter de vette kluif aan te moeten rennen die lokale PS-kopstukken elkaar toewierpen teneinde zelf niet onder te gaan in de heftige factiestrijd. De Karambenor raakte hierdoor steeds meer gepolitiseerd en door haar achterban steeds meer vereenzelvigd met de PS. Voor veel Diola waren leden van de Karambenór dan ook 'schapen in wolfskleren' geworden. Zo mislukte deze poging van de overheid om gevoelens van ontevredenheid bij de Diola te kanaliseren.

Het verval van de Karambenor illustreert een voortdurend ongenoegen onder de Diola met de zucht naar hegemonie van Dakar. De gelijktijdige heropleving van de MFDC als Diola-protestbeweging was dan ook te verwachten. De acht jaar van regelmatig terugkerend geweld die hierop volgen maken de voortdurende discrepantie tussen overheid en Diola ("Casamançais") op lugubere wijze duidelijk.

\section{Conclusie}

Ik heb geprobeerd aan te tonen dat de politisering van oude organisatievormen binnen de Diola-samenleving, met name het adjiatisysteem, niet alleen een gevolg 
was van schaalvergroting (wisselwerking tussen dorpssamenlevingen en bredere sociaal-politiek- economische ontwikkelingen). Veel kon op het conto geschreven worden van de specifieke wijze waarop het regime in Dakar naar hegemonie streefde en de republiek Senegal vestigde. In navolging van de ervaringen in de rest van Senegal waar hele gebieden onder invloed van het PS-partijorgaan kwamen door inkapseling van enkele lokale leiders, probeerde de regering van Senghor en later van Abdou Diouf deze structuur ook te enten op lokale organisatievormen in Casamance. Onder de Diola kon deze enting echter niet hetzelfde verlopen als in de rest van Senegal omdat sterke lokale leiders die het gedrag van een uitgebreide achterban konden bepalen geheel ontbraken (inherent aan hun machtsbasis hadden de adjiati een geografisch beperkte macht). Het starre vasthouden aan dit koppelingspatroon leidde tot de vergroeiingen die in dit artikel naar voren zijn gekomen: onevenwichtige investeringen in de regio als gevolg van wat omvang en geografische uitstraling betreft zeer beperkte machtsblokken; grondonteigeningen zonder voldoende overleg met plaatselijke autoriteiten; hevige factiestrijd die voornamelijk gefinancierd werd door oneigenlijke toewijzing van kavels tijdens wijkverbeteringsprogramma's.

Op dit hegemonisch streven werd door de lokale bevolking verschillend gereageerd. $\mathrm{Zij}$ die profiteerden van de (tijdelijke) geneugten om te kunnen snoepen van de staatskoek als leidende factie en zij die hun kans afwachtten als rivaliserende factie of oppositiepartij. Het zal duidelijk zijn dat verkiezingen enorme fluctuaties binnen deze structuur konden veroorzaken, omdat juist dan weer nieuwe prijzen werden verdeeld. Naast deze nieuwe politiek- economische relaties bleven tegelijkertijd de oude, meer verwantschappelijke, relaties een invloedrijke rol spelen. Dit kan tot het verwarrende beeld leiden dat de lokale bevolking zich enerzijds de mooiste krenten uit de overheidspap kon toeëigenen om vervolgens zonder problemen de "weldoener" in te wisselen voor een ander. Aan de andere kant bleef men sterk hechten aan, in de ogen van een buitenstaander, "onpraktische" relaties. De Diola hadden geheel eigen strategieën ontwikkeld teneinde de sociaal-culturele veranderingen in de loop der tijd te absorberen. Zo pasten zij zich op hun termen en conform hun belangen aan binnen het vanuit Dakar opgelegde moderne staatsbestel (11). Dit verklaarde ook de, in onze ogen ambivalente, omgang met grondgebruik, dat zo makkelijk leek te worden overgedragen, en de (tijdelijke) acceptatie van de politiek-economische escapades van hun belangrijkste adjiati.

Belangrijker op dit punt is de constatering dat niet alleen gekeken moet worden naar de gevolgen van moderne invloeden van buiten op lokale culturen. Interne tegenstellingen binnen lokale samenlevingen kunnen tijdens de transformatie niet alleen een grote rol spelen, maar nog steeds dominant aanwezig zijn (zie Geschiere, 
1989). Juist de marxistische benadering van o.a. Rey, Maillassoux en Bayart levert de instrumenten om dit complexe beeld te ontrafelen.

Zo kan de MFDC gezien worden als uiterlijke vertoning van kracht van de nog steeds aanwezige oude organisatiepatronen. Aan de oppervlakte gedreven als collectief Diola-protest tegen de wijze waarop de regering in Dakar haar hegemonisch streven inhoud had gegeven. In navolging van de politieke macht van marabouts in het aardnootbekken zocht het regime ook in Casamance onder de Diola naar sterke leiders. Inkapseling van deze leiders zou ertoe leiden dat de hele regio onder de hegemonie van het regime zou vallen. In grote mate gebeurde dit inderdaad in het aardnootbekken en andere delen van Senegal waar de organisatiestructuren voortvloeiden uit van oudsher hiërarchische samenlevingen (koninkrijken, kastemaatschappij). Zo'n basis ontbrak evenwel bij de Diola. Daar was sprake van een gefragmenteerd leiderschap, dat in de koloniale en post-koloniale periode weliswaar onderhevig was aan de nodige transformaties, maar waar het leiderschap nooit was verworden tot een netwerk van afhankelijkheidsrelaties tussen een grote groep afhankelijken en én leider die én of meerdere lagen van de bovenbouw beheerste (religie, politiek, enz.).

De verschillende regimes in Dakar gaven politiek-economische macht aan figuren die in de ogen van de lokale bevolking deze machtsconcentratie niet mochten opeisen. Persoonlijke vergoeding (op linie-, wijk- of dorpsniveau) deed vele Diola de schouders ophalen voor zoveel domheid. Maar zodra deze onterechte machtsconcentratie in hun nadeel ging werken kwam er direct protest. Eerst individueel, later steeds meer in collectief verband.

De MFDC kan gezien worden als voorlopig hoogtepunt van deze organisatievorm binnen de protestuitingen. Maar tegelijkertijd is hiermee ook de zwakte van de organisatiestructuur binnen de MFDC aangetoond. Gezien het anarchistische verleden is het niet te verwachten dat de MFDC een gesloten en hechte eenheid vormt. Het is dan ook tekenend dat zowel het witboek van de Senegalese regering over de onlusten in Casamance (22/01/1991) als het rapport van Amnesty International (januari 1991) diverse moorden in verband brengen met persoonlijke en politieke afrekeningen.

Door hun sterke gebondenheid met grond bestaat er altijd een nauwe band met het geboortedorp en dus ook met de organisatievormen aldaar. Nog steeds verzamelt zich én keer in de twintig tot vijfentwintig jaar de hele diaspora van dorpsgenoten teneinde de besnijdenis rituelen mee te maken. Minister, metselaar of akkerbouwer, allen zullen komen en zich onderwerpen aan de aanwezige autoriteit. Dit nu is de kracht van verwantschapssolidariteit. Dat de verwantschapsorganisatie een eigen 
dynamiek kent en dus niet als statisch bezien moet worden heb ik in dit artikel aangetoond door te wijzen op interne tegenstellingen. De kracht van mijn invalshoek - een antropologische benadering "van onderop" met marxistische uitgangspunten - moet met deze casus aangetoond zijn. Mijn aandachtspunten zijn de interne tegenstellingen binnen de Diolasamenleving en de historische analyse van het streven naar hegemonie door de verschillende regimes in Dakar. De enting van nieuwe politiek- economische relaties - van staatsformatie en vernieuwd grondenrecht - op de organisatievormen bij de Diola blijkt moeizaam te verlopen. Beschrijving van het specifieke koppelingspatroon heeft geleid tot een beter inzicht in de recente, bloedige confrontaties in Casamance die het gevolg zijn van deze, voorlopig, mislukte symbiose.

\section{NOTEN}

1.- De auteur is in 1986 aan de Vrije Universiteit te Amsterdam afgestudeerd als socioloog van niet-westerse samenlevingen. In 1985 en enkele daarop volgende jaren, verbleef hij als studentenbegeleider voor telkens meerdere maanden in Senegal.

In 1989 heeft hij samen met mensen van de Vrije Universiteit en de Technische Universiteit te Delft de Stichting Ter Ondersteuning van Zelfbouw Activiteiten in Senegal (STOZAS) opgericht. Deze stichting zonder winstoogmerk heeft ten doel het leefmilieu te verbeteren van met name de gedeprivilegieerden in de derde wereld en te zoeken naar lokale oplossingen hiervoor. John Eichelsheim is als directeur van STOZAS momenteel bezig met de uitvoering van een algeheel sanitatie verbeteringsproject in de stad Ziguinchor.

2.- Casamance is de oude benaming voor de meest zuidelijke streek van Senegal en zij strekt zich bijna even ver landinwaarts als de landen waartussen het ligt ingeklemd: Gambia in het noorden en Guinee Bissau in het zuiden.

De streek is opgedeeld in Basse-Casamance, grenzend aan de Atlantische Oceaan, Moyenne-Casamance dat begint bij de grote mangrove Soungrougrou en Haute-Casamance dat ongeveer eindigt op de meest oostelijke lijn Gambia - Guinee Bissau. De Casamance regio is in 1984 opgedeeld in de regio Kolda en de regio Ziguinchor. De regio Ziguinchor beslaat hierbij het hele gebied dat voordien bekend stond als Basse-Casamance.

3.- In Senegal zelf spreekt men ook wel van 'clan' in plaats van factie. Zo schrijft Zuccarelli, de biograaf van de PS, het volgende:

"le clan est une formation non-statutaire du parti dominant regroupant un certain nombre de militants autour d'un responsable. Il s'agit d'un lien personnel presque toujours dénué de fondement idéologique" (Zuccarelli, 1970: 79).

Clanleiders trekken volgelingen (cliënten) aan door middel van de voordelen (status, prestige en materiële zaken) die zij schenken, in ruil voor de politieke steun en de stemmen die clanleden hun leiders leveren. Als deze groepen en netwerken van cliëntèles met elkaar op het politieke toneel in competitie raken, dan worden zij facties genoemd (Hesseling, 1982: 298). 
4.- Prestigegoederen, en dan vooral vee, werden steeds meer verworven door middel van geld en niet meer geruild tegen rijst. Zie voor de monetarisering van de prestigegoederen Van der Klei, 1989.

5.- CFA $=$ Communauté Financière Africaine. Alle landen die tot de Westafrikaanse Monetaire Unie behoren hanteren deze munteenheid die is gekoppeld aan de Franse franc: 100 F CFA = 2 FF. De Banque Centrale des Etats de l'Afrique de l'Ouest (BCEAO), gevestigd in Dakar, fungeert als emissiebank.

6.- Casamance is een van de regenrijkste streken van Senegal en gold als een van de meest vruchtbare gebieden van het voormalige Frans West-Afrika (Documentation Francaise 1950: 52). Zie ook Van der Klei, 1989.

\section{7.- Zie noot 4 en Van der Klei, 1989.}

8.- Vlak na de onafhankelijkheid streefde Senghor naar een staatsbestel dat werd geleid door een almachtige eenheidspartij. Oppositie werd opgeslokt of verboden en feitelijk was er sprake van een eenpartijstelsel. In 1976 werden drie partijen toegelaten die moesten voldoen aan vastgestelde, officiële ideologieën: liberaal-democratisch, socialistisch-democratisch en communistisch. In $1978 \mathrm{kwam}$ daar een vierde, conservatieve, stroming bij. Op 24 april 1981, dus in de eerste maanden van het nieuwe regime onder Abdou Diouf, verviel de beperking van het aantal partijen en de verplichting om binnen een van de grondwettelijk vastgelegde ideologieën te passen. Zie verder Hesseling, 1982.

9.- Eenduidige toewijzingscriteria stonden niet op papier. In principe had elk hoofd van een huishouden dat reeds in de wijk woonde (ook als huurder) recht op een kavel. Indien de bewoner grote investeringen had gedaan kon hij aanspraak maken op meerdere kavels. Maar in feite werd alles beslist door de toewijzingscommissie. Pas in 1985 zijn pogingen ondernomen om eenduidige toewijzingscriteria op papier te zetten. Zie verder Eichelsheim, 1986.

10.- De opgeloste conflictgevallen betroffen veelal buren en konden vaak opgelost worden door middel van enkele wijzigingen in de scheidslijnen tussen de kavels. De moeilijke gevallen hadden vaak betrekking op een vermeende aanspraak op de kavel door verschillende partijen. Zie voor meer informatie Eichelsheim, 1986.

11.- Hoewel Geschiere in zijn inauguratierede in 1989 enkel het verband tussen "Cultuur en Ontwikkeling" behandelt, ben ik van mening dat deze inzichten ook gelden voor staatsvorming. $\mathrm{Hij}$ geeft in zijn rede enkele illustraties van de eigen dynamiek van lokale culturen die belangrijk zijn voor de manier waarop boeren zich "Ontwikkeling" toeëigenen. Het is een constante strijd van boeren om toegang te krijgen tot ontwikkeling en deze strijd leveren ze op hun termen en conform hun belangen. Belangrijk zijn dan ook de ervaringen van boerensamenlevingen die zij in deze strijd opdoen in de koloniale en postkoloniale tijd. Zie verder Geschiere, 1989. 


\section{BIBLIOGRAFIE}

Adams, Adrian.

1977 Le long voyage des gens du Fleuve,

Paris: Maspero.

Amnesty International

1990 Torture: The Casamance Case, AI Index: AFR 49/02/90

London: International Secretariat

Amnesty International

1991 An Escalation in Human Rights Violations in Casamance Region, AI Index: AFR 49/01/91

London: International Secretariat

Bates, R.H.

1983 Essays in the political economy of rural Africa,

Cambridge: University Press. Binsbergen, W.M.J. van, \& Geschiere. P. (eds.)

1982 Qude productiewijzen en binnendringend kapitalisme: Antropologische verkenningen in Afrika,

Amsterdam: VU-boekhandel.

1985 Old Modes of Production and Capitalist Encroachment,

London/Boston: Kegan Paul International.

Bruneau, J.C.

1979 La croissance urbaine dans les pays tropicaux, Ziguinchor en Casamance, Talence, France: Centre d'etudes de Geographie Tropicale.

Buijtenhuis \& Geschiere (eds.)

1978 Stratification and Class Formation, African Perspectives,

Leiden: Afrika-studiecentrum.

Carvalho, Andre F.

1983 Sectorial Policy and Regional Development: Rice farming policy, implementation and its impact on Casamance and Fleuve (Senegal),

Amsterdam: Universiteit van Amsterdam.

Coquery-Vidrovitch, $\mathbf{C}$.

1985 Afrique Noire,

Paris: Payot.

Cottingham, $\mathrm{C}$

1970 Clan politics and rural modernization: a study of local political change in Senegal, Berkeley: University of California. 
Coulon, $\mathbf{C}$.

1975 Autonomie locale et integration nationale au Sénégal, Paris: Pedone.

Cruise O'Brien, D.B.

1971 The Mourides of Senegal,

Oxford: Clarendon Press.

Dijk, M.P. van,

1980 De informele sector van Ouagadougou en Dakar: ontwikkelingsmogelijkheden van

kleine bedrijven in twee West Afrikaanse hoofdsteden,

Meppel: Krips repro.

Drift, A.J.M. van der

1986 Islam en Staatspenetratie in Senegal: Religie en Macht bij de Diola en de Wolof, Amsterdam: Vrije Universiteit.

Eichelsheim, J.L.

1984 Grondverdeling in Lyndiane, Ziguinchor: veldwerkverslag doctoraal leeronderzoek Sociologie der Niet-Westerse Samenlevingen aan de Vrije Universiteit, Amsterdam: eigen beheer.

1985 La situation foncière a Ziguinchor. théorie et pratique: rapport pour l'I.E.A.N. à Dakar, Senegal, Amsterdam: Vrije Universiteit.

1986 Hoe spontaan zijn "spontane" woonwijken; de problematiek rond herverkaveling in Ziguinchor, Senegal,

Amsterdam: eigen beheer.

t.p. De kracht van oude grondenrechten binnen een moderne staat: de problemen rond stadsontwikkeling in een Senegalese stad.

Eichelsheim, J.L. \& v.d. Klei, J.M.

1985 'C'est la politique, Monsieur: oude en nieuwe landvoogden in Ziguinchor'; in Research Reports,

Leiden: Afrika Studiecentrum.

Ernst, H.

1965 Senegal,

Bonn: Schroeder.

Geschiere, P.

1982 Village Communities and the State, Changing Relations among the Maka of Southeastern Cameroon since the Colonial conquest,

London: Kegan Paul International, Monographs African Studies Centre, Leiden.

1984 'Hegemonische regimes en volksverzet in postkoloniaal Afrika: Bayart, Gramsci en de staat in Kameroen', Sociologische Gids 1984/4 (Themanummer Staatsvorming in Afrika, red. H.Claessen en P.Geschiere) p. 344-369. 
1984 'La paysannerie africaine est-elle captive? Sur la the'se de Goran Hyden et pour une re'ponse plus nuance'e', Politique Africaine 14: 13-34.

1985 'The mode of production concept and the usefulness in African studies - applications of the lineage mode', Canadian Joumal of African Studies 1985, 1: 80-91 (themanummer Modes of Production Debate, B.Jewsiewicki en J.Le'tourneau, eds.).

1987 'Marxistische Antropologie: Nederlandse bijdragen tot het produktiewijzendebat in: Antropologische Verkenningen $6 / 2$ Muiderberg: Coutinho b.v.

1989 'Moderne mythen; cultuur en ontwikkeling in Afrika', inauguratierede Leiden: Rijksuniversiteit

Geschiere, P. \& Klei, J.M. van der

1985 La relation Etat-Paysans et ses ambivalences, EHESS article pour Table ronde "l'etat contemporain",

Paris.

Hesseling, Gerti

1982 Senegal, Staatrechtelijke en politieke ontwikkelingen,

Amsterdam: Kluwer.

1983 Grondenrecht in een juridische overgangssituatie Senegal, tussentijds rapport, Leiden: Afrika Studiecentrum.

Hyden, G.

1980 Beyond Ujamaa in Tanzania, Underdevelopment and an Uncaptured Peasantry, London: Heinemann.

Jonge, K., de en anderen,

1978 Les Migrations en Basse-Casamance (Se'ne'gal) Rapport Final, Leiden: Afrika Studiecentrum.

Klei, J.M., van der,

1978 'Customary land tenure and land reform: the rise of new inequalities among the Diola of Senegal', in: R.Buijtenhuijs \& P.Geschiere 1978: 35-45.

1985 'Articulation of modes of production and the beginning of labour migration among the Diola of Senegal', in: v. Binsbergen \& Geschiere 1985: 71-94.

Lavroff, D.G. (ed.)

1978 Aux umes l'Afrique! Elections et pouvoirs en Afrique noire, Paris: Pedone.

Livre Blanc, Republique du Sénégal,

1991 Les Faits en Casamance: le Droit contre la Violence

Dakar: NIS

Mac Kenzie, W.J.M. and Robinson, Kenneth (eds)

1960 Five Elections in Africa,

Oxford: Clarendon Press. 
Martens, George R.

1983 Relations professionnelles et l'évolution politique au Senegal.

Geneve: Institut International d'Etudes Sociales, no. 74.

Ministère de l'Intérieur de la République du Sénégal

1984 Guide pratique du conseiller municipal,

Rufisque: Imprimerie Nationale no.4017.

Ministère de l'Intérieur de la République du Sénégal

1984 Guide pratique du conseiller rural,

Rufisque: Imprimerie Nationale no. 4018.

Nelson, H.D. e.a.

1974 Area handbook for Senegal.

Washington: US-printing Office.

Osmont, Annick

1983 'Pratiques foncières a Rufisque, Senegal',

Colloque International de St. Riquier, France.

Pelissier, $\mathbf{P}$.

1966 Les paysans du Sénégal.

Saint-Yrieux: Imp. Fabreque.

Raatgever, $\mathbf{R}$.

1988 De verwantschappelijke economie, essays in de historisch-materialistische antropolo-

gie,

Brugge: Walleyndruk NV.

Roche, Ch.

1973 Conquête et résistance des peuples de Casamance (1830-1920);

Dakar: Nouvelles Editions Africaines.

Schachter-Morgenthau, Ruth

1964 Political Parties in french-speaking West Africa,

Oxford: Clarendon Press.

Stel, A. van

1984 Van paaltjes, percelen en politiek; veldwerkverslag doctoraal leeronderzoek,

Amsterdam: Vrije Universiteit.

Zuccarelli, F.

1970 Un parti politique africain: l'UPS,

Paris: Pichon \& Durand-Auzias. 